TITLE:

\title{
Preferential adsorption of cell adhesive proteins from complex media on self-assembled monolayers and its effect on subsequent cell adhesion.
}

\section{$\operatorname{AUTHOR}(\mathrm{S}):$}

Arima, Yusuke; Iwata, Hiroo

\section{CITATION:}

Arima, Yusuke ...[et al]. Preferential adsorption of cell adhesive proteins from complex media on self-assembled monolayers and its effect on subsequent cell adhesion.. Acta biomaterialia 2015, 26: 72-81

\section{ISSUE DATE:}

2015-10-15

URL:

http://hdl.handle.net/2433/202836

\section{RIGHT:}

(c) 2015. This manuscript version is made available under the CC-BY-NC-ND 4.0 license

http://creativecommons.org/licenses/by-nc-nd/4.0/; The full-text file will be made open to the public on 15 October 2017 in accordance with publisher's 'Terms and Conditions for Self-Archiving'.; この論文は出版社版でありません。引 用の際には出版社版をご確認ご利用ください。; This is not the published version. Please cite only the published version. 
Preferential adsorption of cell adhesive proteins from complex media on self-assembled monolayers and its effect on subsequent cell adhesion

Yusuke Arima and Hiroo Iwata*

Institute for Frontier Medical Sciences, Kyoto University, 53 Kawahara-cho, Shogoin, Sakyo-ku, Kyoto 606-8507, Japan

\section{Corresponding Author}

* TEL\&FAX: +81-75-751-4119

E-mail: iwata@frontier.kyoto-u.ac.jp 


\section{Abstract}

We examined the effect of surface chemistry on adsorption of fibronectin (Fn) and vitronectin (Vn) and subsequent cell adhesion, employing self-assembled monolayers (SAMs) of alkanethiols carrying terminal methyl $\left(\mathrm{CH}_{3}\right)$, hydroxyl groups $(\mathrm{OH})$, carboxylic acid $(\mathrm{COOH})$, and amine $\left(\mathrm{NH}_{2}\right)$. More Fn and $\mathrm{Vn}$ adsorbed to $\mathrm{COOH}-$ and $\mathrm{NH}_{2}-\mathrm{SAMs}$ than to $\mathrm{CH}_{3}$ - and $\mathrm{OH}-\mathrm{SAMs}$ from a mixture with bovine serum albumin (BSA) and from $2 \%$ fetal bovine serum. Adhesion of human umbilical vein endothelial cells (HUVECs) on $\mathrm{CH}_{3}$ - and $\mathrm{OH}-\mathrm{SAM}$ s preadsorbed with $\mathrm{Fn}$ and BSA decreased with decreasing adsorbed Fn; however, HUVECs adhered to $\mathrm{COOH}-$ and $\mathrm{NH}_{2}$-SAMs even in the presence of BSA at 1000-fold more than Fn in a mixture because of the preferential adsorption of Fn and/or displacement of preadsorbed BSA with Fn and Vn in a serum-containing medium. SAMs coated with a mixture of Vn and BSA exhibited adhesion of HUVECs regardless of surface functional groups. A well-organized focal adhesion complex and actin stress fibers were observed only for $\mathrm{COOH}$ - and $\mathrm{NH}_{2}$-SAMs when SAMs were preadsorbed with $\mathrm{Vn}$ and BSA. These results suggest that $\mathrm{COOH}-$ and $\mathrm{NH}_{2}$-SAMs allow for both cell adhesion and cell spreading because of the high density of cell-binding domains derived from adsorbed Vn.

Key Words: Self-assembled monolayers; Cell adhesion; Preferential protein adsorption; Fibronectin; Vitronectin 


\section{Introduction}

Much effort has been devoted to understanding cell interactions with artificial materials to facilitate the development of medical devices and scaffolds for tissue engineering. However in most cases, cell-material interactions are not clearly understood, and many studies are required to thoroughly characterize many factors relevant to the cell-material interactions for a particular system. These factors include material surface energy, surface electrostatic properties, macro- and micro-surface morphology, surface heterogeneity, functional groups, and the mobility of functional groups on surfaces. Systematic studies of biological responses to artificial materials require surfaces with well-controlled properties. Self-assembled monolayers (SAMs) of alkanethiols, $\mathrm{HS}\left(\mathrm{CH}_{2}\right)_{\mathrm{n}} \mathrm{X}$, where $\mathrm{X}$ denotes various functional groups $[1,2]$, are suitable for studying correlations between biological responses and surface properties. It was reported that cell adhesion behavior is highly dependent on the outermost functional groups of SAMs [3-10].

The process of cell adhesion onto a material's surface includes the interaction between integrins in the cell membrane and adhesive proteins, such as fibronectin (Fn) and vitronectin (Vn), adsorbed on the surface. Role of Fn and $\mathrm{Vn}$ in cell adhesion on material surfaces has been extensively studied using polymer substrates [11-16] and SAMs [17-22]. Pretreatment of artificial materials with a solution containing either Fn only or Vn only improves cell adhesion to the surfaces. Realistically, however, cell adhesion onto surfaces occurs in tissue fluids, plasma, or culture media supplemented with serum, all of which contain various kinds of proteins. The adsorption behaviors of Fn-only and Vn-only solutions differ from that of complex media, because concentrations of cell adhesive proteins in serum (Fn: $30 \mu \mathrm{g} / \mathrm{mL}$ [23]; Vn: $200 \mu \mathrm{g} / \mathrm{mL}$ [24]) are several orders of magnitude lower than some other proteins, such as bovine serum albumin (BSA, $35-55 \mathrm{mg} / \mathrm{mL})$ and immunoglobulin $\mathrm{G}(\operatorname{IgG}, 0.8-1.8 \mathrm{mg} / \mathrm{mL})$, which lack the capacity to interact 
with cells. This would imply that a protein-adsorbed layer mainly consists of serum proteins that do not mediate cell adhesion.

We aimed to understand how minute amounts of Fn and Vn in complex media can mediate cell adhesion to SAMs presenting different surface properties. In this study, we examined adsorption of Fn and Vn to SAMs in the case of mixed solutions with BSA or fetal bovine serum (FBS), as well as displacement of initially adsorbed proteins by Fn and Vn. We also tested adhesion of human umbilical vein endothelial cells (HUVECs) and formation of focal adhesion complexes on these SAMs to elucidate the relationship between adsorption of Fn and Vn and cellular behavior.

\section{Materials and methods}

\subsection{Materials}

1-Dodecanethiol ( $\mathrm{CH}_{3}$ : Wako Pure Chemical Industries, Ltd., Osaka, Japan), 11-mercapto-1undecanol (OH: Sigma-Aldrich, St. Louis, MO, USA), 11-mercaptoundecanoic acid (COOH: Sigma-Aldrich), and 11-amino-1-undecanethiol hydrochloride $\left(\mathrm{NH}_{2}\right.$ : Dojindo Laboratories, Kumamoto, Japan) were used as received. Dulbecco's (D) phosphate-buffered saline (PBS) (DPBS: $137 \mathrm{mM} \mathrm{NaCl}, 2.7 \mathrm{mM} \mathrm{KCl}, 8.1 \mathrm{mM} \mathrm{Na} 2 \mathrm{HPO}_{4}, 1.5 \mathrm{mM} \mathrm{KH}_{2} \mathrm{PO}_{4}, \mathrm{pH} 7.4$ ) was purchased from Nissui Pharmaceutical Co., Ltd (Tokyo, Japan). Human plasma Fn (F2006), bovine plasma Vn (V9881), and BSA (A4503) were purchased from Sigma-Aldrich and used as received. Antibodies against integrin $\alpha_{5}$ (AB1928, Millipore, Billerica, MA, USA) and integrin $\alpha_{\mathrm{v}}(\mathrm{ab} 16821$, Abcam, Cambridge, UK) were used as received. Alexa Fluor 488 anti-rabbit IgG, Alexa Fluor 488 anti-mouse IgG, and Alexa Fluor 594 phalloidin were purchased from Molecular Probes, Inc. (Eugene, OR, USA). 


\subsection{Preparation of SAMs}

Cover glasses (diameter; 15 mm, Matsunami Glass Ind., Ltd., Osaka, Japan) were cleaned by oxygen plasma treatment using a plasma reactor (PA300AT, O-kuma Engineering Co. Ltd., Fukuoka, Japan) for $1 \mathrm{~min}$ and rinsed with highly purified water (18.2 M $\Omega)$ and with ethanol three times. Cleaned cover glasses were coated with a chromium underlayer of $1 \mathrm{~nm}$ and then a gold layer of $19 \mathrm{~nm}$ in thickness by a thermal evaporation apparatus (V-KS200, Osaka Vacuum Instruments, Osaka, Japan). The gold-coated cover glasses were immediately immersed in a $1 \mathrm{mM}$ solution of alkanethiols overnight to form SAMs. The cover glasses were then rinsed with ethanol and water twice and finally with ethanol, and then dried under a stream of nitrogen gas.

\subsection{Surface characterization}

Elemental compositions of the SAM surfaces were determined by X-ray photoelectron spectroscopy (XPS) using an ESCA 850V (Shimadzu Co., Kyoto, Japan) equipped with a Mg Ka source. The take-off angle was $90^{\circ}$, and the operating pressure was lower than $1 \times 10^{-5} \mathrm{~Pa}$. All spectra were shown referring to $\mathrm{Au}\left(4 \mathrm{f}_{7 / 2}\right)$ at $83.8 \mathrm{eV}$.

Static water contact angles were determined by the sessile drop method using a contact angle meter (CA-X; Kyowa Interface Science Co. Ltd., Saitama, Japan) at room temperature. A droplet $(10 \mu \mathrm{L})$ of water was placed on a SAM surface, and $10 \mathrm{sec}$ later, the contact angle was determined three times. This procedure was repeated five times at different sites on the same surface, and the contact angle of a sample was expressed as the mean value of five contact angle measurements with SEM.

\subsection{Adsorption of Fn and Vn}


Fn and Vn were radiolabeled using the chloramine-T method [25]. Five microliters of $\mathrm{Na}^{125} \mathrm{I}$ (Iodine-125, PerkinElmer Inc., Boston, MA, USA) and $100 \mu \mathrm{L}$ of chloramine-T (Nacalai Tesque, Kyoto, Japan; $0.2 \mathrm{mg} / \mathrm{mL}$ in $0.5 \mathrm{M}$ phosphate buffer containing $0.15 \mathrm{M} \mathrm{NaCl}, \mathrm{pH} 7.4$ ) was added to $200 \mu \mathrm{L}$ of Fn or $\mathrm{Vn}(500 \mu \mathrm{g} / \mathrm{mL}$ in $0.5 \mathrm{M}$ phosphate buffer containing $0.15 \mathrm{M} \mathrm{NaCl})$. For $\mathrm{Vn}$, $50 \mu \mathrm{g} / \mathrm{mL}$ of stock solution was concentrated by ultrafiltration (Amicon Ultra-0.5, nominal molecular weight limit: 10000; Millipore) before radiolabeling. The reaction mixture was incubated for $2 \mathrm{~min}$ at room temperature. Then $100 \mu \mathrm{L}$ of sodium metabisulfite (Nacalai Tesque; $4 \mathrm{mg} / \mathrm{mL}$ in water) was added to stop the reaction. Labeled proteins were separated by sizeexclusion chromatography using a Sephadex G-25 column (PD-10; GE Healthcare Bio-Sciences Corp., Piscataway, NJ, USA). Fractions were collected and examined for radioactivity using a gamma counter (ARC-380CL, Aloka Co., Ltd., Tokyo, Japan). Protein concentration was also determined by the Micro BCA ${ }^{\mathrm{TM}}$ protein assay (Thermo Fisher Scientific Inc., Rockford, IL, USA). Labeled proteins were mixed with unlabeled proteins, and specific activity (cpm/ng-protein) was determined. The sample was stored at $-20^{\circ} \mathrm{C}$ until use. A control protein adsorption experiment was performed using ${ }^{125}$ I-labeled proteins with a different ratio to non-labeled proteins. The adsorbed amount of proteins was constant regardless of the ratio (data not shown), suggesting that the iodination of Fn and Vn does not change their adsorption behavior.

A $100 \mu \mathrm{L}$ droplet of protein solution, dissolved in DPBS containing $10 \mathrm{mM} \mathrm{NaI}$ (PBSI) [26], was placed on a 35-mm non-treated polystyrene dish (Asahi Techno Glass Corp., Tokyo, Japan), and substrate-carrying SAM was immediately floated on the droplet so that the SAM surface faced the protein solution. The substrate was placed on the droplet immediately in order to avoid formation of protein layer at air-water interface of the droplet. The concentration of Fn or Vn was kept constant at $0.01 \mathrm{mg} / \mathrm{mL}$ while BSA concentration was varied at $0.01-10 \mathrm{mg} / \mathrm{mL}$ in PBSI. 
After 30 min incubation at $37^{\circ} \mathrm{C}$, the substrates were rinsed with PBSI and placed in polystyrene tubes. The radioactivities (cpm) were measured by the gamma counter and converted to the amount of adsorbed $\mathrm{Fn}$ or $\mathrm{Vn}\left(\mathrm{ng} / \mathrm{cm}^{2}\right)$. In some experiments, to observe displacement of adsorbed proteins, SAMs were first incubated with $10 \mathrm{mg} / \mathrm{mL}$ BSA for $30 \mathrm{~min}$ and then rinsed with PBSI followed by incubation with either ${ }^{125} \mathrm{I}$-labeled Fn or Vn for $30 \mathrm{~min}$.

Protein adsorption to SAMs from FBS was also tested. Fn contained in native FBS was removed using gelatin Sepharose [27]. FBS was mixed with gelatin Sepharose 4B (GE Healthcare) and incubated for $2 \mathrm{~h}$ at room temperature. Fn-depleted FBS was collected by centrifugation at 1000 $\times \mathrm{g}$ for 2 min using a filter unit (ULTRAFREE-MC; Millipore). Removal of Fn was confirmed by ELISA. ${ }^{125}$ I-labeled Fn was then added to a concentration of $30 \mu \mathrm{g} / \mathrm{mL}$. For Vn, ${ }^{125} \mathrm{I}$-labeled Vn was added to native FBS at a concentration of $20 \mu \mathrm{g} / \mathrm{mL}$, which is one tenth of the $\mathrm{Vn}$ concentration in native FBS [24]. A protein adsorption experiment was performed as described above. The amount of adsorbed Fn was calculated from radioactivity while that of adsorbed Vn was calculated from radioactivity and then multiplied by 11 because the FBS included ${ }^{125}$ I-labeled Vn and native Vn with a presumed ratio of 1:10.

\subsection{Cell culture}

HUVECs (Lonza, Walkersville, MD, USA) were maintained on tissue culture dishes at $37^{\circ} \mathrm{C}$ in $5 \% \mathrm{CO}_{2}$. The culture medium, prepared by following the instructions from the HUVECs supplier, was Endothelial Basal Medium (EBM-2, Lonza) supplemented with 2\% FBS (Lonza) and with the growth factors hFGF-B, VEGF, R3-IGF-1, and hEGF, and also containing hydrocortisone, ascorbic acid, heparin, gentamicin, and amphotericin-B (Lonza). Cells were collected by the addition of a $0.025 \%$ trypsin/ $0.01 \%$ EDTA solution (Lonza). Cells in passages from 4 to 5 were 
collected and used for the cell adhesion assay. The culture medium containing EBM-2, 2\% FBS, gentamicin, and amphotericin-B was used in the cell adhesion tests and is referred to here as the assay medium.

\subsection{Cell adhesion to SAMs preadsorbed with proteins}

SAMs, formed on the gold-coated cover glasses as described above, were immersed in $70 \%$ ethanol and placed in a 24-well non-treated polystyrene plate (Asahi Techno Glass Corp.). The SAMs were incubated with $10 \mu \mathrm{g} / \mathrm{mL}$ Fn or Vn solutions in DPBS or $0.01-10 \mathrm{mg} / \mathrm{mL}$ BSA at $37^{\circ} \mathrm{C}$ for $30 \mathrm{~min}$. The surface was then washed with DPBS three times and once with the assay medium. Collection of HUVECs by the addition of trypsin/EDTA was carefully monitored and terminated at the point of rounding up of the cells in order to minimize damage to cell surface components. Cells were washed once and then suspended in either the assay medium, or the serumfree medium which contains only $1 \mathrm{mg} / \mathrm{mL}$ BSA (same as BSA concentration in $2 \% \mathrm{FBS}$ ). A suspension of HUVECs was added to each well at a density of $1 \times 10^{4}$ cells $/ \mathrm{cm}^{2}$ and incubated at $37{ }^{\circ} \mathrm{C}$ in $5 \% \mathrm{CO}_{2}$. After $1 \mathrm{~h}$ of culture, phase-contrast images of the cells were taken using an inverted microscope (IX71, Olympus, Tokyo, Japan) with a 10× objective. Cells were washed with warm DPBS three times to remove non-adherent cells and then fixed with $4 \%$ paraformaldehyde (PFA; Nacalai Tesque) in DPBS for 20 min. After the fixed cells were washed with DPBS three times, cell nuclei were stained with $2 \mu \mathrm{g} / \mathrm{mL}$ of Hoechst 33258 (Dojindo Laboratories) in $20 \mathrm{mM}$ Tris-HCl buffered solution ( $\mathrm{pH}$ 8.0) for $20 \mathrm{~min}$. The number of adherent cells on each surface was determined by counting the number of stained nuclei using a fluorescence microscope $(10 \times$ objective lens) in 10 different fields. 


\subsection{Immunostaining}

HUVECs were cultured on SAMs preadsorbed with Fn or Vn as described above. After $1 \mathrm{~h}$ of incubation, cells were rinsed with warm DPBS three times and fixed with PBS solution containing 4\% PFA for $20 \mathrm{~min}$. Cells were permeabilized by treatment with $0.5 \%$ TritonX-100 solution at room temperature for $5 \mathrm{~min}$ and then treated with $2 \%$ skim milk solution for $1 \mathrm{~h}$ to block nonspecific adsorption of antibodies, followed by incubation with the primary antibody against integrin $\alpha_{5}\left(1: 200\right.$ in 2\% skim milk) for Fn-coated SAMs or integrin $\alpha_{\mathrm{v}}(1: 200$ in $2 \%$ skim milk) for Vn-coated SAMs for $1 \mathrm{~h}$ at $4{ }^{\circ} \mathrm{C}$. After washing with PBS containing 0.05\% Tween-20, cells were treated with Alexa Fluor 488 anti-rabbit IgG (integrin $\alpha_{5}$ ) or Alexa Fluor 488 anti-mouse IgG (integrin $\left.\alpha_{\mathrm{v}}\right)\left(1: 500\right.$ in $2 \%$ skim milk) for $1 \mathrm{~h}$ at $4{ }^{\circ} \mathrm{C}$ and washed with PBS containing $0.05 \%$ Tween-20. Actin filaments were stained with Alexa Fluor 594-conjugated phalloidin (1:40 in DPBS) for 20 min at room temperature and rinsed with DPBS. Samples were mounted on cover glasses with Vectashield containing 4',6-diamidino-2-phenylindole (DAPI) (Vector Laboratories, Inc., Burlingame, CA, USA) and observed with a confocal fluorescence microscope (FV10i, Olympus).

\subsection{Statistical analysis}

Significant differences between two groups were examined using the Tukey's HSD test. A $p<$ 0.05 was considered as statistically significant. All statistical calculations were performed using JMP, version 7.0.1 (SAS Institute, Cary, NC).

\section{Results}

\subsection{Surface characterization}


SAMs carrying four different functionalities $\left(\mathrm{CH}_{3}-, \mathrm{OH}-, \mathrm{COOH}-, \mathrm{NH}_{2}-\right)$ were chosen since they are typical functional groups present in polymer substrates and hence commonly examined for protein adsorption and cell adhesion studies [3-10,17-22]. Surface properties of the SAMs were characterized by XPS and water contact angle measurements (Table 1). Most of the atomic compositions obtained were in good agreement with those expected from the molecular structures of alkanethiols. The water contact angles were in agreement with those reported in the literature [19]. These analyses confirmed that the expected SAM surfaces were formed on the gold surface.

\subsection{Adsorption of Fn and Vn}

\subsubsection{Adsorption from single and mixed solution with BSA}

We measured the amounts of Fn and Vn adsorbed to SAMs in either single or mixed protein solution using ${ }^{125} \mathrm{I}$-labeled proteins. Concentrations of Fn or Vn were kept constant at $10 \mu \mathrm{g} / \mathrm{mL}$ while BSA concentration was varied from 0 to $10 \mathrm{mg} / \mathrm{mL}$. Total amounts of adsorbed proteins were also determined by a surface plasmon resonance (SPR) apparatus. Total amounts of adsorbed Fn and BSA showed no dependence on Fn/BSA ratios, while those of Vn and BSA to COOH- and $\mathrm{NH}_{2}$-SAMs showed maximum at $\mathrm{Vn} / \mathrm{BSA}$ of 0.001 (Supplementary Figure 1). When SAM surfaces were exposed to single Fn solution, a larger amount of $\mathrm{Fn}$ was adsorbed to $\mathrm{CH}_{3}-, \mathrm{COOH}-$, and $\mathrm{NH}_{2}$-SAMs than to OH-SAMs (Fig. 1a), in consistent with other reports [19]. The adsorbed amounts of Fn decreased with a decrease in the Fn/BSA ratio. However, the decrement differed with the surface functional group of the SAMs: The adsorbed amount of Fn was greatly reduced for $\mathrm{CH}_{3}$ - and $\mathrm{OH}-\mathrm{SAMs}$ but remained large for $\mathrm{COOH}$ - and $\mathrm{NH}_{2}-\mathrm{SAMs}$. Even for Fn/BSA = 0.001, which is similar to the ratio of Fn and BSA in FBS (Fn: $30 \mu \mathrm{g} / \mathrm{mL}$; BSA: $35-55 \mathrm{mg} / \mathrm{mL}$ ), Fn 
adsorbed to $\mathrm{COOH}-$ and $\mathrm{NH}_{2}-\mathrm{SAMs}$ at $40 \%$ and $15 \%$ of that from the single Fn solution, respectively.

Adsorption of Vn exhibited a similar tendency to that of Fn. Larger amounts of Vn were adsorbed to $\mathrm{CH}_{3}-$ and $\mathrm{NH}_{2}$-SAMs than to $\mathrm{OH}-$ and $\mathrm{COOH}-\mathrm{SAMs}$ from single Vn solution (Fig. 1b). Although adsorption of $\mathrm{Vn}$ to $\mathrm{CH}_{3}$ - and $\mathrm{OH}-\mathrm{SAMs}$ was markedly decreased in the presence of BSA, it was still observed for $\mathrm{COOH}$ - and $\mathrm{NH}_{2}-\mathrm{SAMs}$. For $\mathrm{Vn} / \mathrm{BSA}=0.01$, which is similar to FBS (Vn: $200 \mu \mathrm{g} / \mathrm{mL}$, BSA: $35-55 \mathrm{mg} / \mathrm{mL}$ ), the amount of adsorbed Vn decreased to only $60 \%$ for both $\mathrm{COOH}-$ and $\mathrm{NH}_{2}$-SAMs while it decreased to $\sim 10 \%$ for $\mathrm{CH}_{3}-$ and $\mathrm{OH}-\mathrm{SAMs}$.

\subsubsection{Adsorption of Fn and Vn from FBS}

We also examined adsorption of Fn and Vn to SAMs from FBS using ${ }^{125}$ I-labeled Fn or Vn. To ensure that radioactivity was in the measurable range, ${ }^{125}$ I-labeled Fn (final concentration: 30 $\mu \mathrm{g} / \mathrm{mL}$ ) was added to Fn-depleted FBS while ${ }^{125} \mathrm{I}$-labeled Vn (final concentration: $20 \mu \mathrm{g} / \mathrm{mL}$, one tenth of that in native FBS) was added to native FBS. Adsorption of Fn and Vn from 2\% FBS, which corresponds to the culture condition of HUVECs, was greatly influenced by the surface functional group of SAMs as follows (Fig. 2): $\mathrm{COOH}->\mathrm{NH}_{2}->\mathrm{CH}_{3}-\approx \mathrm{OH}-\mathrm{SAM}$ for Fn and $\mathrm{NH}_{2}->\mathrm{COOH}->\mathrm{OH}-\approx \mathrm{CH}_{3}-\mathrm{SAM}$ for $\mathrm{Vn}$, respectively. Preferential adsorption of Fn and Vn were also observed from FBS, and larger amounts of Vn adsorbed to SAMs than Fn. Additionally, the tendency of adsorption was similar to protein adsorption from the mixed solution with BSA where ratios of cell adhesive proteins to BSA were similar to those in FBS (Fn/BSA $=0.001$ for Fn and $\mathrm{Vn} / \mathrm{BSA}=0.01$ for $\mathrm{Vn}$, respectively). These results suggest that adsorption of cell adhesive proteins from FBS mainly results from competitive adsorption with BSA. 


\subsubsection{Adsorption of Fn and Vn to SAMs preadsorbed with BSA}

Considering that the concentration of BSA in serum is much higher than that of Fn or $\mathrm{Vn}$, it is to be expected that a protein-adsorbed layer from FBS mainly would consist of BSA at the initial phase of adsorption. In such a case, adsorbed BSA would need to be displaced with Fn and Vn. To examine displacement of BSA with cell adhesive proteins, SAMs were incubated with $1 \mathrm{mg} / \mathrm{mL}$ BSA for 30 min followed by incubation with either ${ }^{125}$ I-labeled Fn or Vn. The adsorbed amounts of both Fn and Vn on $\mathrm{COOH}$ - and $\mathrm{NH}_{2}$-SAMs were higher than those on $\mathrm{CH}_{3}$ - and $\mathrm{OH}-\mathrm{SAMs}$ (Fig. 3), suggesting that $\mathrm{COOH}-$ and $\mathrm{NH}_{2}-\mathrm{SAMs}$ allow for displacement of preadsorbed BSA with Fn and Vn.

\subsection{Cell adhesion to SAMs preadsorbed with Fn and Vn}

HUVECs were used to examine cell adhesion behavior to SAMs preadsorbed with Fn or Vn mixed with BSA. Figure 4 shows the number of adhered HUVECs on SAMs preadsorbed with different ratios of Fn/BSA or Vn/BSA mixtures. Most of adherent cells ( $>95 \%$ ) were viable for all conditions as tested by staining with calcein-AM (live cells) and propidium iodide (dead cells) (data not shown). When BSA/Fn ratio was relatively high (Fn only and Fn/BSA $\geq 0.1$ ), the numbers of adhered cells were similar among the SAMs (Fig. 4a). The numbers of adherent cells drastically decreased for $\mathrm{CH}_{3}$-SAMs and for $\mathrm{OH}-\mathrm{SAMs}$ with decreasing Fn/BSA ratio. In contrast, large amounts of cells adhered on $\mathrm{COOH}-$ and $\mathrm{NH}_{2}$-SAMs preadsorbed with Fn/BSA of 0.001 . To study the role of FBS in culture medium on cell adhesion, HUVECs were incubated on SAMs preadsorbed with Fn/BSA in serum-free medium containing only $1 \mathrm{mg} / \mathrm{mL}$ BSA (Fig. 4b). HUVECs adhered to COOH-SAM preadsorbed with Fn/BSA of 0.001 even in the serum-free medium and hardly adhered to that preadsorbed with only BSA, coinciding with preferential 
adsorption of Fn on COOH-SAM. In contrast, adhesion of HUVECs observed for $\mathrm{NH}_{2}$-SAM preadsorbed with only BSA. This suggest that some non-biospecific interaction or electrostatic interaction between cell surface and $\mathrm{NH}_{2}-\mathrm{SAM}$ covered with BSA contributed to initial cell adhesion.

In addition, cells adhered to COOH-SAM preadsorbed with only BSA ( $~ 50 \%$ of those for Fnadsorbed SAMs), in agreement with our previous studies $[9,10]$. Considering the experimental conditions in which cells are incubated in a medium supplemented with $2 \%$ FBS, preadsorbed BSA is thought to be displaced with serum proteins included in FBS. Cell adhesion was greatly suppressed for COOH-SAM preadsorbed with single BSA when cells were incubated in the serumfree medium. These results suggest that displacement of BSA with Fn or Vn, both of which are included in a serum-containing medium, is also important to mediate cell adhesion to surfaces.

Preadsorption of single Vn solution enabled HUVECs to adhere to SAMs independently of the SAM surface functional group (Fig. 4c). Of note, no significant difference in the numbers of adhered cells was observed among SAMs preadsorbed with a Vn/BSA of 0.001 . This was also observed when cells were incubated in the serum-free medium (Fig. 4d). Preadsorption of SAMs with only BSA did not change the number of adherent cells for $\mathrm{NH}_{2}$-SAMs and slightly decreased for $\mathrm{CH}_{3}$ - and $\mathrm{OH}-\mathrm{SAMs}$, suggesting the contribution of non-biospecific or electrostatic interaction to cell adhesion. In contrast, for COOH-SAM, presence of Vn greatly increased the number of adherent cells in both cases. These results clearly suggest that preferential adsorption of $\mathrm{Vn}$ mediate adhesion of HUVECs to COOH-SAM.

\subsection{Formation of focal adhesion and actin stress fibers}


Spreading of HUVECs on SAMs preadsorbed with either Fn or Vn was evaluated in terms of formation of focal adhesion complexes and actin stress fibers. Cells were immunostained with antibodies against integrin $\alpha_{5}$ for Fn-adsorbed surfaces and integrin $\alpha_{v}$ for Vn-adsorbed surfaces, which are major integrins interacting with $\mathrm{Fn}\left(\alpha_{5} \beta_{1}\right)$ and $\mathrm{Vn}\left(\alpha_{v} \beta_{3}\right)$, respectively. F-actin was also stained with fluorescently labeled phalloidin to observe stress fiber formation.

HUVECs adhered on SAMs preadsorbed with single Fn exhibited clear clusters of integrins $\alpha_{5}$, which are co-localized with actin stress fibers (Fig. 5a), indicating formation of well-organized focal adhesion. When HUVECs were cultured on SAMs preadsorbed with Fn/BSA of 0.001, lessdeveloped F-actin fibers and no obvious cluster of integrins were observed for COOH-SAMs, indicating reduced formation of focal adhesion (Fig. 5b). For $\mathrm{NH}_{2}-\mathrm{SAMs}$, diffuse F-actin and no cluster of integrins were observed. Fewer HUVECs adhered to $\mathrm{CH}_{3}$ - and $\mathrm{OH}-\mathrm{SAMs}$ preadsorbed with Fn/BSA of 0.001 as shown in Figure 4a, and adherent HUVECs exhibited no clustering either of integrin or F-actin.

In the case of SAMs preadsorbed with single Vn, robust clusters of integrin $\alpha_{\mathrm{v}}$ and actin stress fibers were observed for all SAMs (Fig. 6a), indicating formation of well-organized focal adhesions on Vn-coated SAM surfaces. For SAMs preadsorbed with a Vn/BSA of 0.001, however, no clustering of integrin or F-actin was observed for $\mathrm{CH}_{3}$ - and $\mathrm{OH}-\mathrm{SAMs}$ whereas HUVECs on $\mathrm{COOH}-$ and $\mathrm{NH}_{2}$-SAMs exhibited clusters of integrin and actin stress fibers (Fig. 6b). These results suggest that $\mathrm{Vn}$ adsorbed on $\mathrm{COOH}$ - and $\mathrm{NH}_{2}$-SAMs efficiently mediates formation of the focal adhesion complex while that adsorbed on $\mathrm{CH}_{3}$ - and $\mathrm{OH}-\mathrm{SAMs}$ supports attachment of HUVECs but not formation of focal adhesion complexes.

\section{Discussion}


We have employed SAMs carrying four different functionalities $\left(\mathrm{CH}_{3}^{-}, \mathrm{OH}-, \mathrm{COOH}-, \mathrm{NH}_{2}-\right)$ and their mixed SAMs for protein adsorption and cell adhesion studies since they are typical functional groups present in polymer substrates and hence commonly examined [3-10,17-22]. XPS analysis of the SAMs indicated that most of the atomic compositions obtained were in agreement with those expected from the molecular structures of alkanethiols (Table 1). Sulfur percentages were smaller than expected values estimated from molecular formula in all SAMs. This might be due to the attenuation of the photoelectrons emitted from the S-Au interface which must reach the detector through the SAM layer. In addition, the presence of oxygen in $\mathrm{NH}_{2}$-SAM surfaces might have been the result of oxidized sulfur species, as Wang et al [28] suggested. The water contact angles were in agreement with those reported in the literature [19]. These analyses confirmed that the expected SAM surfaces were formed on the gold surface.

We have shown that HUVECs adhere well to $\mathrm{COOH}$ - and $\mathrm{NH}_{2}$-SAMs but poorly to $\mathrm{OH}-\mathrm{SAMs}$ and hardly at all to $\mathrm{CH}_{3}-\mathrm{SAMs}$ [9]. In our study which examined the effect of surface wettability on protein adsorption and subsequent cell adhesion using mixed SAMs of two different alkanethiols [10], we found that the number of adherent cells was at its maximum on SAMs with moderate wettability $\left(40-60^{\circ}\right)$, although wettability varied slightly by the combination of surface functional groups and cell type. Our previous investigation of real-time monitoring of protein adsorption and cell adhesion using an SPR apparatus and a total internal reflection fluorescence microscope also demonstrated that serum proteins rapidly adsorbed to SAM surfaces within $1 \mathrm{~min}$ while cells adhered during the first $1 \mathrm{~h}$ [9], demonstrating clearly that adsorption of serum proteins contributes to a SAM's suitability for cell adhesion. Moreover, on $\mathrm{COOH}-$ and $\mathrm{NH}_{2}-\mathrm{SAMs}$, HUVECs adhesion to BSA-preadsorbed surfaces in medium containing 2\% FBS was delayed by several minutes compared to HUVEC adhesion to bare surfaces, suggesting that displacement of 
preadsorbed BSA with cell adhesive proteins, such as Fn or Vn, supports cell adhesion to these surfaces. These previous results led us to further examine the competitive adsorption of cell adhesive proteins onto SAMs carrying different functional groups.

This study focused on adsorption of Fn and Vn to SAMs from complex media including mixed solution with BSA and 2\% FBS, and its role on cell adhesion. HUVECs adhered well to all SAMs preadsorbed with single solution of either Fn or Vn, indicating that Fn or Vn with high coverage effectively mediates cell adhesion. In contrast, the surface functional group of SAMs greatly affected adsorption of Fn and Vn in the presence of BSA (Fig. 1); larger amounts of Fn and Vn adsorbed on $\mathrm{COOH}-$ and $\mathrm{NH}_{2}-\mathrm{SAMs}$ than on $\mathrm{CH}_{3}-$ and $\mathrm{OH}-\mathrm{SAMs}$. A similar tendency was observed for adsorption of Fn and Vn from 2\% FBS (Fig. 2). The difference in the adsorbed amount between Fn and Vn arises from the difference in their concentrations in FBS. Greater adsorption of Fn and Vn to surfaces having carboxylic acid and amine are consistent with other studies using tissue culture polystyrene (TCPS) and Primaria ${ }^{\mathrm{TM}}$ [15] and self-assembled monolayers of alkyl silanes [8]. We previously measured the total amounts of adsorbed serum proteins on the SAMs from culture medium supplemented with 2\% FBS using SPR [9], identifying $198 \mathrm{ng} / \mathrm{cm}^{2}$ for $\mathrm{CH}_{3}-, 180 \mathrm{ng} / \mathrm{cm}^{2}$ for $\mathrm{OH}-, 226 \mathrm{ng} / \mathrm{cm}^{2}$ for $\mathrm{COOH}-$, and $256 \mathrm{ng} / \mathrm{cm}^{2}$ for $\mathrm{NH}_{2-}$ SAMs, respectively. The amounts of adsorbed Fn determined in this study were calculated to be $0.11 \%$ for $\mathrm{CH}_{3}-, 0.06 \%$ for $\mathrm{OH}-, 1.32 \%$ for $\mathrm{COOH}-$, and $0.29 \%$ for $\mathrm{NH}_{2}-\mathrm{SAMs}$, of total amount of adsorbed serum proteins. The amounts of adsorbed Vn were also calculated to be $0.67 \%$ for $\mathrm{CH}_{3}-, 1.09 \%$ for $\mathrm{OH}-, 3.57 \%$ for $\mathrm{COOH}-$, and $6.84 \%$ for $\mathrm{NH}_{2}-\mathrm{SAMs}$, respectively. Percentages of Fn and $\mathrm{Vn}$ included in the protein-adsorbed layers on $\mathrm{COOH}-$ and $\mathrm{NH}_{2}-\mathrm{SAMs}$ were much larger than those in FBS (Fn: 0.04\%, Vn: 0.29\%), which are estimated by assuming total protein 
concentration of FBS to be $70 \mathrm{mg} / \mathrm{mL}$. Our results clearly demonstrate that Fn and $\mathrm{Vn}$ are effectively accumulated on $\mathrm{COOH}$ - and $\mathrm{NH}_{2}$-SAMs from complex media.

Vroman showed that fibrinogen from plasma at intermediate dilution adsorbs only transiently over a short interval [29]. This phenomenon, referred to as the Vroman effect, has been shown to result from competitive adsorption and displacement of adsorbed proteins with other proteins in the fluid phase [30]. Because of the low content of Fn and Vn in FBS, a protein layer at the initial phase of protein adsorption mostly consists of major serum proteins lacking cell-binding activity such as BSA and IgG. Displacement of initially adsorbed proteins with Fn and Vn is considered to be involved in preferential adsorption of Fn and Vn according to the Vroman effect, in which faster diffusing molecules are considered to be displaced by proteins with a higher affinity for surface $[30,31]$. Our result indicated that $\mathrm{COOH}-$ and $\mathrm{NH}_{2}-\mathrm{SAMs}$ exhibited better adsorption of Fn and Vn after preadsorption of BSA for 30 min (Fig. 3), suggesting displacement of preadsorbed BSA with Fn and Vn. Displacement of preadsorbed BSA might be related to its conformational change $[32,33]$. Circular dichroism (CD) spectroscopic study by Sivaraman et al demonstrated that adsorption of albumin on hydrophobic $\mathrm{CH}_{3}-\mathrm{SAM}$ induced greater conformational change than on hydrophilic surfaces $\left(\mathrm{OH}-, \mathrm{COOH}-, \mathrm{NH}_{2}-\mathrm{SAMs}\right)$ [34]. Conformational change of adsorbed proteins on hydrophobic surfaces is also shown by molecular simulation [35] and Fourier transform infrared spectroscopy [36]. While strongly (or irreversibly) adsorbing albumin to $\mathrm{CH}_{3}-$ SAM would inhibit displacement with other proteins in liquid phase, weakly (or reversibly) adsorbing albumin to hydrophilic SAMs would allow for the displacement [32,37]. Affinity of Fn with OH-SAM, however, was not so strong as shown by poor adsorption of Fn to OH-SAM (Fig. 1a). Therefore, preferential adsorption of Fn did not occur for OH-SAM. Preferential adsorption of Fn and $\mathrm{Vn}$ for $\mathrm{COOH}-$ and $\mathrm{NH}_{2}-\mathrm{SAMs}$ is considered to result from displacement of initially 
adsorbed BSA with Fn and Vn due to relatively weak interaction of BSA with $\mathrm{COOH}-$ and $\mathrm{NH}_{2}-$ SAMs.

Despite the similarity of adsorption behavior to SAMs between Fn and Vn, cell adhesion behavior was greatly different. HUVECs adhered to SAMs preadsorbed with mixtures of Fn and BSA (Fig. 4a), correlating to the number of adsorbed Fn (Fig. 1a). However, HUVECs adhered to SAMs preadsorbed with Vn and BSA regardless of surface functional groups (Fig. 4c), although a much smaller amount of $\mathrm{Vn}$ adsorbed on $\mathrm{CH}_{3}$ - and $\mathrm{OH}-\mathrm{SAMs}$ than on $\mathrm{COOH}-$ and $\mathrm{NH}_{2}-\mathrm{SAMs}$ (Fig. 1b). We consider that this finding can be explained in terms of the number of adhesion sites on SAMs. The tripeptide sequence Arg-Gly-Asp (RGD) is one of the important adhesion sites included in both Fn and Vn and interacts with both integrins $\alpha_{5} \beta_{1}$ and $\alpha_{v} \beta_{3}$ [38]. We calculated RGD density on SAMs carrying adsorbed Fn or Vn from Figure 1 according to their molecular weight (Fn: $440 \mathrm{kDa}$; Vn: $69 \mathrm{kDa}$ ) and number of RGDs (Fn: two; Vn: one per molecule). The numbers of adherent cells (Fig. 4a, 4c) were then plotted against the RGD density (Fig. 7). The RGD densities on $\mathrm{CH}_{3}$-SAM and $\mathrm{OH}-\mathrm{SAMs}$ preadsorbed with $\mathrm{Vn} / \mathrm{BSA}$ of 0.001 (Fig. 7b) were much higher than those preadsorbed with Fn/BSA of 0.001 (Fig. 7a). This result suggests that the higher RGD density for adsorbed Vn than that for adsorbed Fn enables cells to adhere to $\mathrm{CH}_{3}$ SAM and OH-SAMs preadsorbed with Vn/BSA of 0.001. Results in Figure 7 also shows that most of prepared surfaces are located at higher RGD density for $\mathrm{COOH}-$ and $\mathrm{NH}_{2}$-SAMs regardless of Fn/BSA or Vn/BSA, clearly demonstrated that preferential adsorption of Fn and Vn onto COOHand $\mathrm{NH}_{2}$-SAMs supports cell adhesion on these SAM surfaces.

While good adherence of HUVECs on $\mathrm{COOH}$ - and $\mathrm{NH}_{2}$-SAMs preadsorbed with Fn agrees with other study [19], good adherence on $\mathrm{COOH}-$ and $\mathrm{NH}_{2}$-SAMs preadsorbed with $\mathrm{Vn}$ has not been reported. Our result is consistent with other study using polymer substrates. Steele et al. examined 
attachment of HUVECs to TCPS (negatively charged) and Primaria ${ }^{\mathrm{TM}}$ (positively charged) adsorbed with either Fn or Vn [15]. The density of Fn for half-maximal attachment was calculated to be $54 \mathrm{fmol} / \mathrm{cm}^{2}$ for TCPS and $27 \mathrm{fmol} / \mathrm{cm}^{2}$ for Primaria ${ }^{\mathrm{TM}}$, while the density of Vn was 246 $\mathrm{fmol} / \mathrm{cm}^{2}$ for TCPS and $87 \mathrm{fmol} / \mathrm{cm}^{2}$ Primaria ${ }^{\mathrm{TM}}$. Keselowsky et al. examined attachment of osteoblast-like cell line (MC3T3-E1) cells to SAMs preadsorbed with Fn [19]. The density of Fn for half-maximal attachment of cells was calculated to be $1090 \mathrm{fmol} / \mathrm{cm}^{2}$ for $\mathrm{CH}_{3-}, 86 \mathrm{fmol} / \mathrm{cm}^{2}$ for $\mathrm{OH}-, 250 \mathrm{fmol} / \mathrm{cm}^{2}$ for $\mathrm{COOH}-$, and $370 \mathrm{fmol} / \mathrm{cm}^{2}$ for $\mathrm{NH}_{2}-\mathrm{SAMs}$, respectively. Our study showed adhesion of HUVECs at a lower RGD density than previous reports. This reduction is probably attributable to cell adhesion experiments performed in a medium supplemented with $2 \%$ FBS, which allows for displacement of preadsorbed proteins with serum proteins in the medium. In fact, around $50 \%$ of seeded cells could adhere to $\mathrm{COOH}-\mathrm{SAMs}$ preadsorbed with only BSA (Fig. 4a) whereas HUVECs did not adhere in a serum-free medium (Fig. 4b). Although role of 2\% FBS in the medium on cell adhesion for $\mathrm{NH}_{2}-\mathrm{SAM}$ is not clear due to the presence of some nonspecific interaction between cells and BSA-adsorbed $\mathrm{NH}_{2}$-SAM (Fig. 4b), these findings suggest that HUVECs adhere well to COOH-SAMs because of preferential adsorption of both Fn and Vn and displacement of adsorbed BSA with Fn and Vn in a medium.

Although HUVECs adhered to SAMs preadsorbed with Vn and BSA (Vn/BSA: 0.001) regardless of surface functional groups (Fig. 4c), focal adhesion and actin stress fibers were well organized for HUVECs on only $\mathrm{COOH}-$ and $\mathrm{NH}_{2}-\mathrm{SAMs}$ (Fig. 6b). The RGD densities on Vnadsorbed COOH- $\left(535 \mathrm{fmol} / \mathrm{cm}^{2}\right)$ and $\mathrm{NH}_{2}$-SAMs $\left(398 \mathrm{fmol} / \mathrm{cm}^{2}\right)$ were an order of magnitude higher than those on $\mathrm{CH}_{3}-\mathrm{SAM}\left(60 \mathrm{fmol} / \mathrm{cm}^{2}\right)$ and $\mathrm{OH}-\mathrm{SAMs}\left(40 \mathrm{fmol} / \mathrm{cm}^{2}\right)$. This result is consistent with the study reported by Massia et al. [39], which demonstrated that cell spreading and formation of focal contact and stress fiber required more RGDs than cell attachment. In 
addition, the RGD densities on Vn-adsorbed $\mathrm{COOH}-$ and $\mathrm{NH}_{2}-\mathrm{SAMs}$ were higher than those on Fn-adsorbed COOH- $\left(225 \mathrm{fmol} / \mathrm{cm}^{2}\right)$ and $\mathrm{NH}_{2}-\mathrm{SAMs}\left(83 \mathrm{fmol} / \mathrm{cm}^{2}\right)$ in the presence of 1000 -fold BSA. Greater adsorption of $\mathrm{Vn}$ than Fn was also observed in protein adsorption from $2 \% \mathrm{FBS}$, consistent with earlier studies using a variety of polymer substrates $[15,27,40,41]$. Taken together, these results suggest the importance of preferential adsorption of $\mathrm{Vn}$ in mediating cell adhesion on $\mathrm{COOH}-$ and $\mathrm{NH}_{2}-\mathrm{SAMs}$ as reported by the reduction of cell adhesion in a medium supplemented with Vn-depleted serum but not Fn-depleted serum [42].

Present study demonstrated that preferential adsorption of Fn and Vn from complex media is important for subsequent cell adhesion. It is known that conformation of adsorbed protein also plays an important role in its biological function. This is implied by our results that the RGD density necessary for cell adhesion is much higher than that obtained in studies using substrates presenting RGD peptides $[39,43]$. Our results suggest that some Fn and Vn adsorb to SAMs so that their cell-binding domains are inaccessible to integrins because of changes in orientation and conformation upon adsorption. For Fn adsorption, the $\mathrm{CH}_{3}$-SAM required the highest $\mathrm{RGD}$ density while the OH-SAM required the least RGD density (Fig. 7a), suggesting surface-dependent conformational change of adsorbed Fn. Conformational change of adsorbed Fn has been widely studied using SAMs $[19,20,22,44,45]$ and polymer substrates $[11,14,16]$. Keselowsky et al. reported that surface functional groups of SAMs modulate conformation of adsorbed Fn qualitatively determined by binding of monoclonal antibody against their cell binding: $\mathrm{OH}->$ $\mathrm{COOH}-=\mathrm{NH}_{2}->\mathrm{CH}_{3}-\mathrm{SAMs}[19]$. These works studied the conformational change of adsorbed Fn from a single solution. In complex media, coadsorbing proteins affect conformation of adsorbed Fn [46]. To identify the true effect of protein adsorption on cell adhesion in complex media, the density of effective (active) adhesion sites accessible to cells needs to be further quantified by 
characterizing the conformational change of adsorbed Fn and Vn as well as the adsorbed amounts in complex media. Additionally, proteomics and bioinformatics analyses revealed the contribution of other adsorbed proteins to cellular behavior [47]. Combination of these techniques is required to further understand the role of adsorbed protein layer on cellular responses.

This study employed HUVECs to examine cell adhesion behavior to SAMs. Results will provide insights into endothelialization of artificial vascular grafts in vitro for preparing thromboresistant surface. The aim of this study is to understand the role of protein adsorption on cell adhesion at initial phase of cell adhesion process $(\sim 1 \mathrm{~h})$. For effective coverage of materials surface with endothelial cells, cellular behaviors at later stages including growth or thromboresistant ability [48] need to be studied. In addition, relationship between protein adsorption and cell adhesion needs to be examined for a wide variety of cells to further understand cellular behavior on artificial substrates and to design substrates for specific cell types [49-52].

\section{Conclusion}

Adsorption of Fn and Vn was preferential for $\mathrm{COOH}$ - and $\mathrm{NH}_{2}-\mathrm{SAMs}$ compared to $\mathrm{CH}_{3}$ - and $\mathrm{OH}-\mathrm{SAMs}$ in both mixtures with BSA and a medium supplemented with $2 \%$ FBS. HUVECs adhered to SAMs preadsorbed with Fn and BSA depending on the adsorbed amount of Fn while they adhered all SAMs preadsorbed with Vn and BSA. This result was well related to the higher density of RGDs derived from adsorbed Vn than that derived from adsorbed Fn. HUVECs adhered to $\mathrm{COOH}-$ and $\mathrm{NH}_{2}-\mathrm{SAMs}$ preadsorbed with $\mathrm{Vn}$ and BSA exhibited clustering of integrins and well-organized actin stress fibers. These results demonstrate that Vn preferentially adsorbs to $\mathrm{COOH}-$ and $\mathrm{NH}_{2}$-SAMs sufficiently to support both cell adhesion and cell spreading.

\section{Acknowledgement}


This work was supported by a Grant-in-Aid for Scientific Research on Innovative Areas

"Nanomedicine Molecular Science" (No. 2306) and a Grant-in-Aid for Young Scientists (B)

(No. 23700559) from the Ministry of Education, Culture, Sports, Science, and Technology of Japan.

\section{References}

1. Ulman A. Formation and structure of self-assembled monolayers. Chem Rev 1996;96:15331554.

2. Ostuni E, Yan L, Whitesides GM. The interaction of proteins and cells with self-assembled monolayers of alkanethiolates on gold and silver. Colloid Surf B 1999;15:3-30.

3. López GP, Albers MW, Schreiber SL, Carroll RW, Peralta E, Whitesides GM. Convenient methods for patterning the adhesion of mammalian cells to surfaces using self-assembled monolayers of alkanethiolates on gold. J Am Chem Soc 1993;115:5877-5878.

4. Tidwell CD, Ertel SI, Ratner BD, Tarasevich BJ, Atre S, Allara DL. Endothelial cell growth and protein adsorption on terminally functionalized, self-assembled monolayers of alkanethiolates on gold. Langmuir 1997;13:3404-3413.

5. McClary KB, Ugarova T, Grainger DW. Modulating fibroblast adhesion, spreading, and proliferation using self- assembled monolayer films of alkylthiolates on gold. J Biomed Mater Res. 2000;50:428-439.

6. Ostuni E, Chapman RG, Liang MN, Meluleni G, Pier G, Ingber DE, Whitesides GM. Selfassembled monolayers that resist the adsorption of proteins and the adhesion of bacterial and mammalian cells. Langmuir 2001;17:6336-6343. 
7. Scotchford CA, Gilmore CP, Cooper E, Leggett GJ, Downes S. Protein adsorption and human osteoblast-like cell attachment and growth on alkylthiol on gold self-assembled monolayers. J Biomed Mater Res 2000;59:84-99.

8. Faucheux N, Schweiss R, Lützow K, Werner C, Groth T. Self-assembled monolayers with different terminating groups as model substrates for cell adhesion studies. Biomaterials 2004;25:2721-2730.

9. Arima $\mathrm{Y}$, Iwata $\mathrm{H}$. Effects of surface functional groups on protein adsorption and subsequent cell adhesion using self-assembled monolayers. J. Mater. Chem. 2007;17:4079-4087.

10. Arima Y, Iwata H. Effect of wettability and surface functional groups on protein adsorption and cell adhesion using well-defined mixed self-assembled monolayers. Biomaterials 2007;28:3074-3082.

11. Grinnell F, Feld MK. Fibronectin adsorption on hydrophilic and hydrophobic surfaces detected by antibody binding and analyzed during cell adhesion in serum-containing medium. J Biol Chem 1982;257:4888-4893.

12. Bentley KL, Klebe RJ. Fibronectin binding properties of bacteriologic petri plates and tissue culture dishes. J Biomed Mater Res 1985;19:757-769.

13. Van Wachem PB, Mallens BWL, Dekker A, Beugeling T, Feijen J, Bantjes A, Detmers JP, van Aken WG. Adsorption of fibronectin derived from serum and from human endothelial cells onto tissue culture polystyrene. J Biomed Mater Res 1987;21:1317-1327.

14. Pettit DK, Hoffman AS, Horbett TA. Correlation between corneal epithelial cell outgrowth and monoclonal antibody binding to the cell binding domain of adsorbed fibronectin. $\mathrm{J}$ Biomed Mater Res 2004;28:685-691. 
15. Steele JG, Dalton BA, Johnson G, Underwood PA. Adsorption of fibronectin and vitronectin onto Primaria $^{\mathrm{TM}}$ and tissue culture polystyrene and relationship to the mechanism of initial attachment of human vein endothelial cells and BHK-21 fibroblasts. Biomaterials 1995;16:1057-1067.

16. Koenig AL, Gambillara V, Grainger DW. Correlating fibronectin adsorption with endothelial cell adhesion and signaling on polymer substrates. J Biomed Mater Res 2003;64A:20-37.

17. Iuliano DJ, Saavedra SS, Truskey GA. Effect of the conformation and orientation of adsorbed fibronectin on endothelial cell spreading and the strength of adhesion. J Biomed Mater Res. $1993 ; 27: 1103-1113$.

18. Thomas CH, McFarland CD, Jenkins ML, Rezania A, Steel, JG., Healy KE. The role of vitronectin in the attachment and spatial distribution of bone-derived cells on materials with patterned surface chemistry. J Biomed Mater Res 1997;37:81-93.

19. Keselowsky BG, Collard DM, García AJ. Surface chemistry modulates fibronectin conformation and directs integrin binding and specificity to control cell adhesion. J Biomed Mater Res 2003;66A:247-259.

20. Barrias CC, Martins MCL, Almeida-Porada G, Barbosa MA, Granja PL. The correlation between the adsorption of adhesive proteins and cell behavior on hydroxyl-methyl mixed selfassembled monolayers. Biomaterials 2009;30:307-316.

21. Llopis-Hernández V, Rico P, Ballester-Beltrán J, Moratal D, Salmerón-Sánchez M. Role of surface chemistry in protein remodeling at the cell-material interface. Plos One 2011;6:e19610. 
22. Lin M, Wang H, Ruan C, Xing J, Wang J, Li Y, Wang Y, Luo Y. Adsorption force of fibronectin on various surface chemistries and its vital role in osteoblast adhesion. Biomacromolecules 2015;16:973-984.

23. Hayman EG, Ruoslahti E. Distribution of fetal bovine serum fibronectin and endogenous rat cell fibronectin in extracellular matrix. J Cell Biol 1979;83:255-259.

24. Shaffer MC, Foley TP, Barnes DW. Quantitation of spreading factor in human biologic fluids. J Lab Clin Med 1984;103:783-791.

25. Greenwood FC, Hunter WM, Glover JS. The preparation of ${ }^{131}$ I-labelled human growth hormone of high specific radioactivity. Biochem J 1963;89:114-123.

26. Du YJ, Cornelius RM, Brash JL. Measurement of protein adsorption to gold surface by radioiodination methods: suppression of free iodide sorption. Colloid Surf B 2000;17:59-67.

27. Underwood PA, Bennett FA. A comparison of the biological activities of the cell-adhesive proteins vitronectin and fibronectin. J Cell. Sci 1989;93:641-649.

28. Wang H, Chen S, Li L, Jiang S. Improved method for the preparation of carboxylic acid and amine terminated self-assembled monolayers of alkanethiolates. Langmuir 2005;21:26332636.

29. Vroman L, Adams AL. Identification of rapid changes at plasma-solid interfaces. J Biomed Mater Res 1969;3:43-67.

30. Wojciechowski P, Hove PT, Brash JL. Phenomenology and mechanism of the transient adsorption of fibrinogen from plasma (Vroman effect). J Colloid Interface Sci 1986;111:455465. 
31. Vilaseca P, Dawson KA, Franzese G. Understanding and modulating the competitive surfaceadsorption of proteins through coarse-grained molecular dynamics simulations. Soft Matter 2013;9:6978-6985.

32. Wertz CF, Santore MM. Effect of surface hydrophobicity on adsorption and relaxation kinetics of albumin and fibrinogen: Single-species and competitive behavior. Langmuir 2001;17:3006-3016.

33. Jung S, Lim S, Albertorio F, Kim G, Gurau MC, Yang RD, Holden MA, Cremer PS. The Vroman effect: A molecular level description of fibrinogen displacement. J Am Chem Soc $2003 ; 125: 12782-12786$.

34. Sivaraman B, Fears KP, Latour RA. Investigation of the effects of surface chemistry and solution concentration on the conformation of adsorbed proteins using an improved circular dichroism method. Langmuir 2009;25:3050-3056.

35. Mücksch C, Urbassek HM. Molecular dynamics simulation of free and forced BSA adsorption on a hydrophobic graphite surface. Langmuir 2011;27:12938-12943.

36. Roach P, Farrar D, Perry CC. Interpretation of protein adsorption: Surface-induced conformational changes. J Am Chem Soc 2005;127:8168-8173.

37. Kidoaki S, Matsuda T. Adhesion forces of the blood plasma proteins on self-assembled monolayer surfaces of alkanethiolates with different functional groups measured by an atomic force microscope. Langmuir 1999;15:7639-7646.

38. Rouslahti E. RGD and other recognition sequences for integrins. Annu Rev Cell Dev Biol 1996;12:697-715. 
39. Massia SP, Hubbell JA. An RGD spacing of $440 \mathrm{~nm}$ is sufficient for integrin $\alpha_{\mathrm{v}} \beta_{3}$-mediated fibroblast spreading and $140 \mathrm{~nm}$ for focal contact and stress fiber formation. J Cell Biol 1991;114:1089-1100.

40. Fabrizius-Homan DJ, Cooper SL. Competitive adsorption of vitronectin with albumin, fibrinogen, and fibronectin on polymeric biomaterials. J Biomed Mater Res 1991;25:953-971.

41. Bale MD, Wohlfahrt LA, Mosher DF, Tomasini B, Sutton RC. Identification of vitronectin as a major plasma protein adsorbed on polymer surfaces of different copolymer composition. Blood 1989;74:2698-2706.

42. Steele JG, Johnson G, Underwood PA. Role of serum vitronectin and fibronectin in adhesion of fibroblasts following seeding onto tissue culture polystyrene. J Biomed Mater Res 1992;26:861-884.

43. Roberts C, Chen CS, Mrksich M, Martichonok V, Ingber DE, Whitesides GM. Using mixed self-assembled monolayers presenting $\mathrm{RGD}$ and (EG) $)_{3} \mathrm{OH}$ groups to characterize long-term attachment of bovine capillary endothelial cells to surfaces. J Am Chem Soc 1998;120:65486555.

44. Baugh L, Vogel V. Structural changes of fibronectin adsorbed to model surfaces probed by fluorescence resonance energy transfer. J Biomed Mater Res 2004;69A:525-534.

45. Klotzsch E, Schoen I, Ries J, Renn A, Sandoghdare V, Vogel V. Conformational distribution of surface-adsorbed fibronectin molecules explored by single molecule localization microscopy. Biomater Sci 2014;2:883-892.

46. Giamblanco N, Yaseen M, Zhavnerko G, Lu JR, Marletta G. Fibronectin conformation switch induced by coadsorption with human serum albumin. Langmuir 2011;27:312-319. 
47. Yang D, Lü X, Hong Y, Xi T, Zhang D. The molecular mechanism of mediation of adsorbed serum proteins to endothelial cells adhesion and growth on biomaterials. Biomaterials $2013 ; 34: 5747-5758$.

48. McGuigan AP, Sefton MV. The influence of biomaterials on endothelial cell thrombogenicity. Biomaterials;2007;28: 2547-2571.

49. Mei Y, Saha K, Bogatyrev SR, Yang J, Hook AL, Kalcioglu ZI, Cho SW, Mitalipova M, Pyzocha N, Rojas F, Van Vliet KJ, Davies MC, Alexander MR, Langer R, Jaenisch R, Anderson DG. Nat Mater 2010;9:768-778.

50. Irwin EE, Gupta R, Dashti DC, Healy KE. Engineered polymer-media interfaces for the longterm self-renewal of human embryonic stem cells. Biomaterials 2011;32:6912-6919.

51. Villa-Diaz LG, Nandivada H, Ding J, Nogueira-De-Souza NC, Krebsbach PH, O'Shea KS, Lahann J, Smith GD. Synthetic polymer coatings for long-term growth of human embryonic stem cells. Nat Biotechnol 2010;28:581-583.

52. Saha K, Mei Y, Reisterer CM, Pyzocha NK, Yang J, Muffat J, Davies MC, Alexander MR, Langer R, Anderson DG, Jaenisch R. Surface-engineered substrates for improved human pluripotent stem cell culture under fully defined conditions. Proc Natl Acad Sci USA 2011;108:18714-18719. 


\section{Figure legend}

Figure 1. The adsorbed amount of Fn (a) and Vn (b) on SAMs after 30 min of incubation as a function of the weight ratio of Fn or Vn to BSA. Fn and Vn in X-axes indicate single Fn or Vn solution used for protein adsorption experiments. Concentrations of Fn and Vn were kept constant $(10 \mu \mathrm{g} / \mathrm{mL})$ for a series of experiments. Data shown are means $\pm \mathrm{SD}$ ( $n=5$ for Fn; $n=4$ for $\mathrm{Vn})$.

Figure 2. The adsorbed amounts of Fn and Vn on SAMs from 2\% FBS after 30 min of incubation. Data shown are means $\pm \operatorname{SD}(n=5)$. Asterisks indicate significant differences $(p<0.05)$.

Figure 3. The adsorbed amounts of Fn and Vn on SAMs preadsorbed with BSA. SAMs were preadsorbed with $10 \mathrm{mg} / \mathrm{mL}$ BSA followed by incubation in either Fn or Vn solution $(10 \mu \mathrm{g} / \mathrm{mL})$. Data shown are means $\pm \mathrm{SD}(n=5$ for $\mathrm{Fn} ; n=4$ for $\mathrm{Vn})$. Asterisks indicate significant differences $(p<0.05)$

Figure 4. The numbers of adherent HUVECs on SAMs preadsorbed with a mixture of Fn $(a, b)$ or Vn $(\mathrm{c}, \mathrm{d})$ with BSA. Cells were incubated in a medium supplemented with $2 \%$ FBS $(\mathrm{a}, \mathrm{c})$ or a serum-free medium containing only $1 \mathrm{mg} / \mathrm{mL}$ BSA (b, d) for $1 \mathrm{~h}$. Data shown are means $\pm \mathrm{SD}(n$ $=4)$.

Figure 5. Confocal fluorescence images of HUVECs adhered to SAMs preadsorbed with single Fn (a) and Fn/BSA of 0.001 (b). Cells were incubated for $1 \mathrm{~h}$, fixed, permeabilized, and stained for integrin $\alpha_{5}$ (green), F-actin (red), and nucleus (blue). Scale bar: $20 \mu \mathrm{m}$. 
Figure 6. Confocal fluorescence images of HUVECs adhered to SAMs preadsorbed with single Vn (a) and Vn/BSA of 0.001 (b). Cells were incubated for $1 \mathrm{~h}$, fixed, permeabilized, and stained for integrin $\alpha_{\mathrm{v}}$ (green), F-actin (red), and nucleus (blue). Scale bar: $20 \mu \mathrm{m}$.

Figure 7. Relationship between RGD densities and adhesion of HUVECs for SAMs preadsorbed with Fn/BSA (a) and Vn/BSA (b). The RGD density is calculated from Fig. 1, and the number of adherent cells is the same as in Fig. 4a and c. 


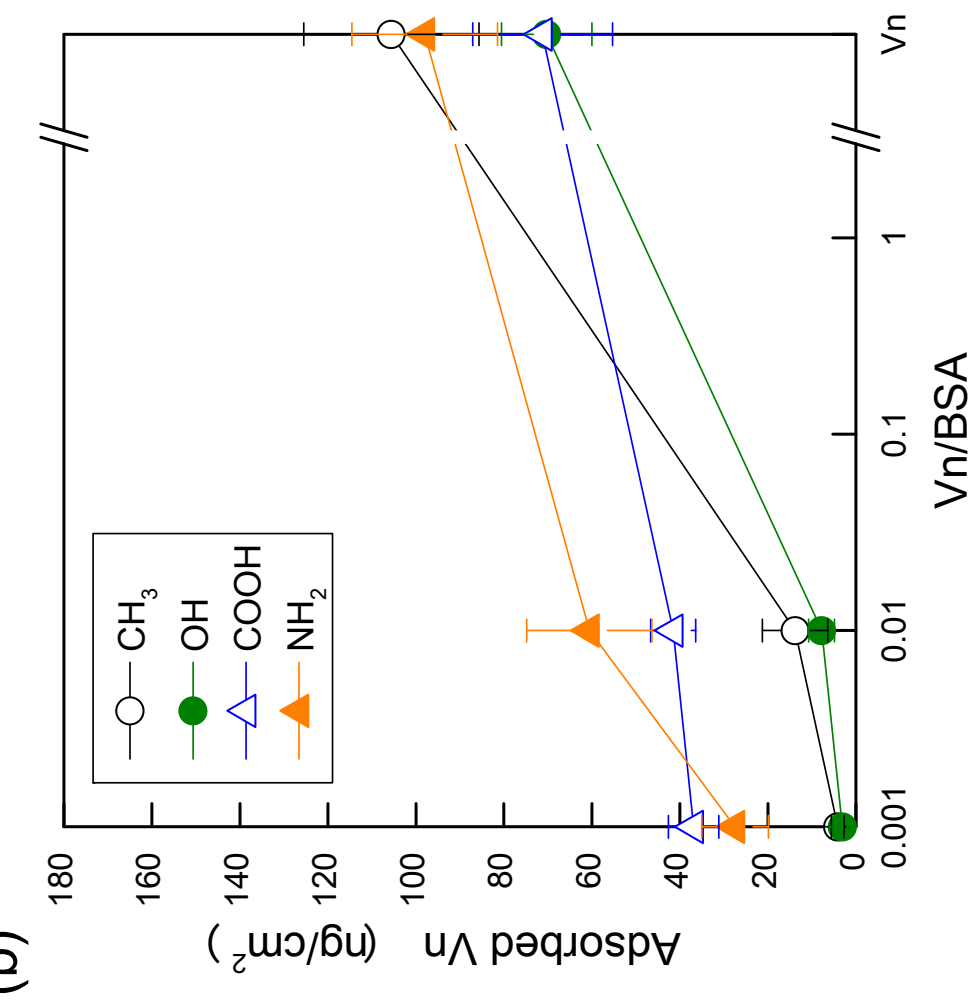

옥

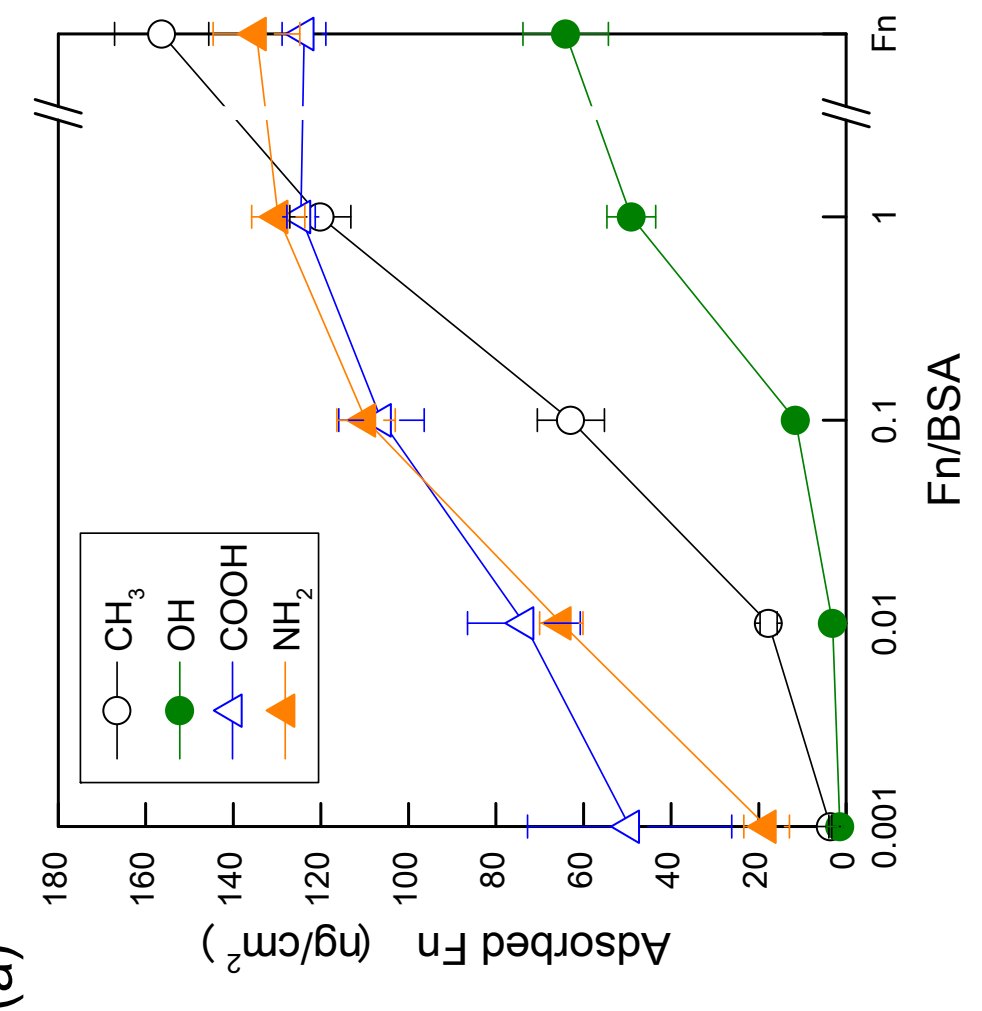




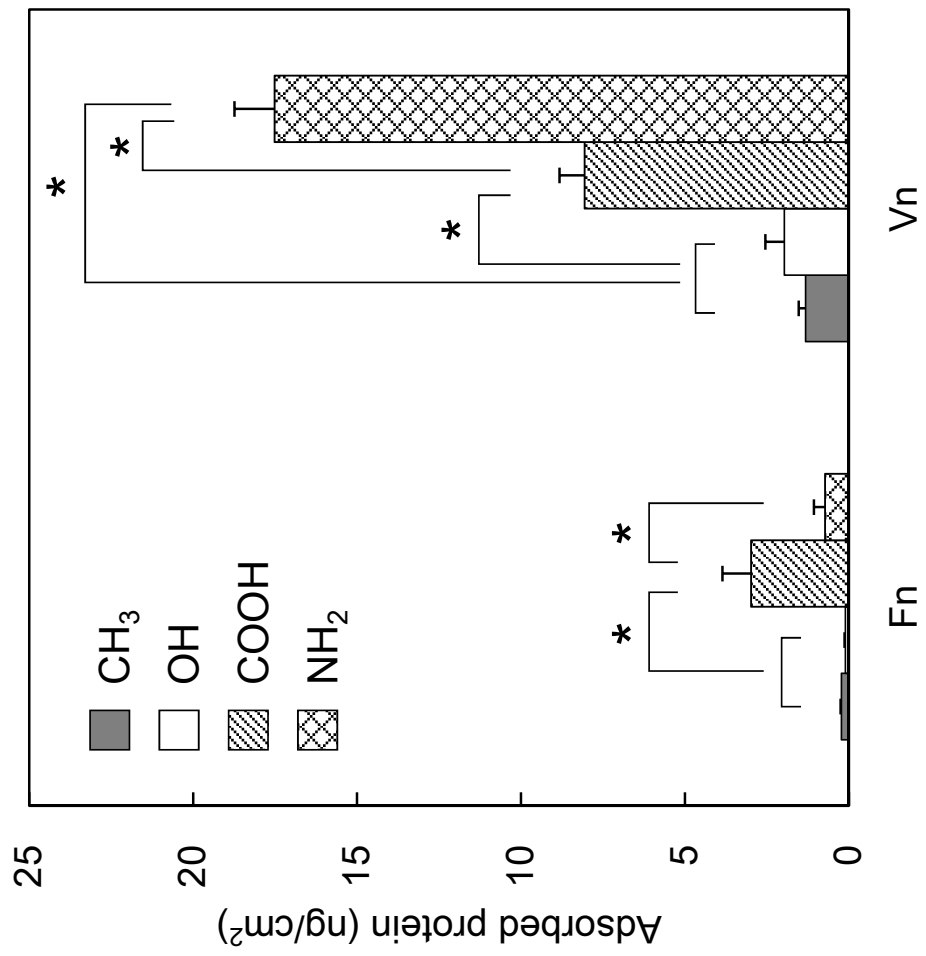


$m$
$\frac{0}{2}$
$\frac{0}{2}$

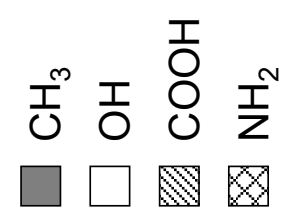

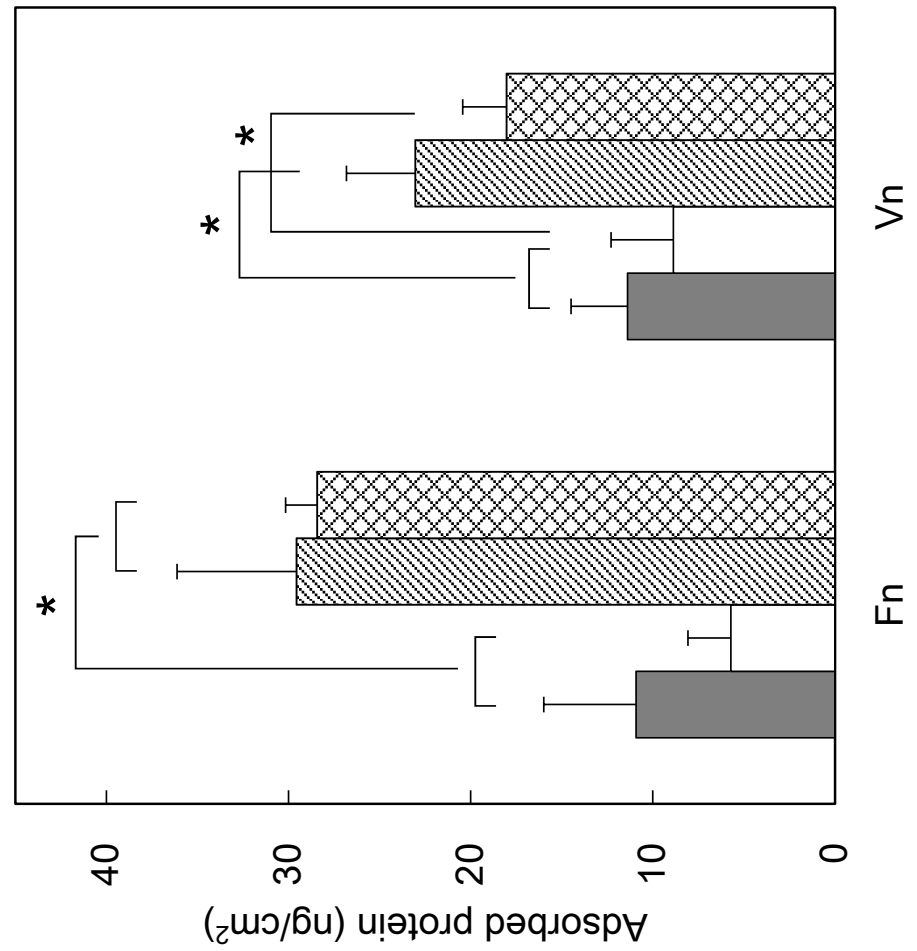



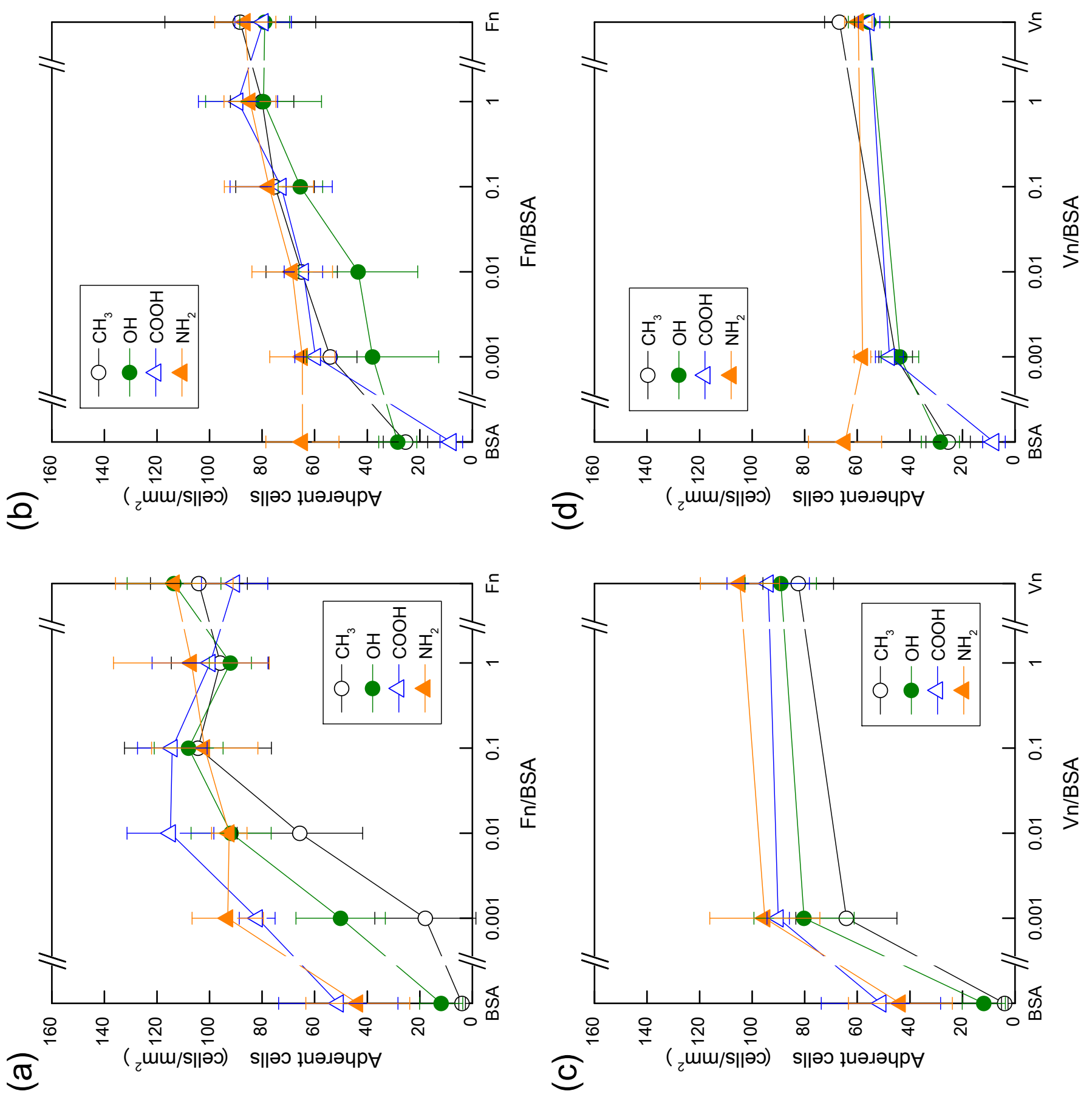

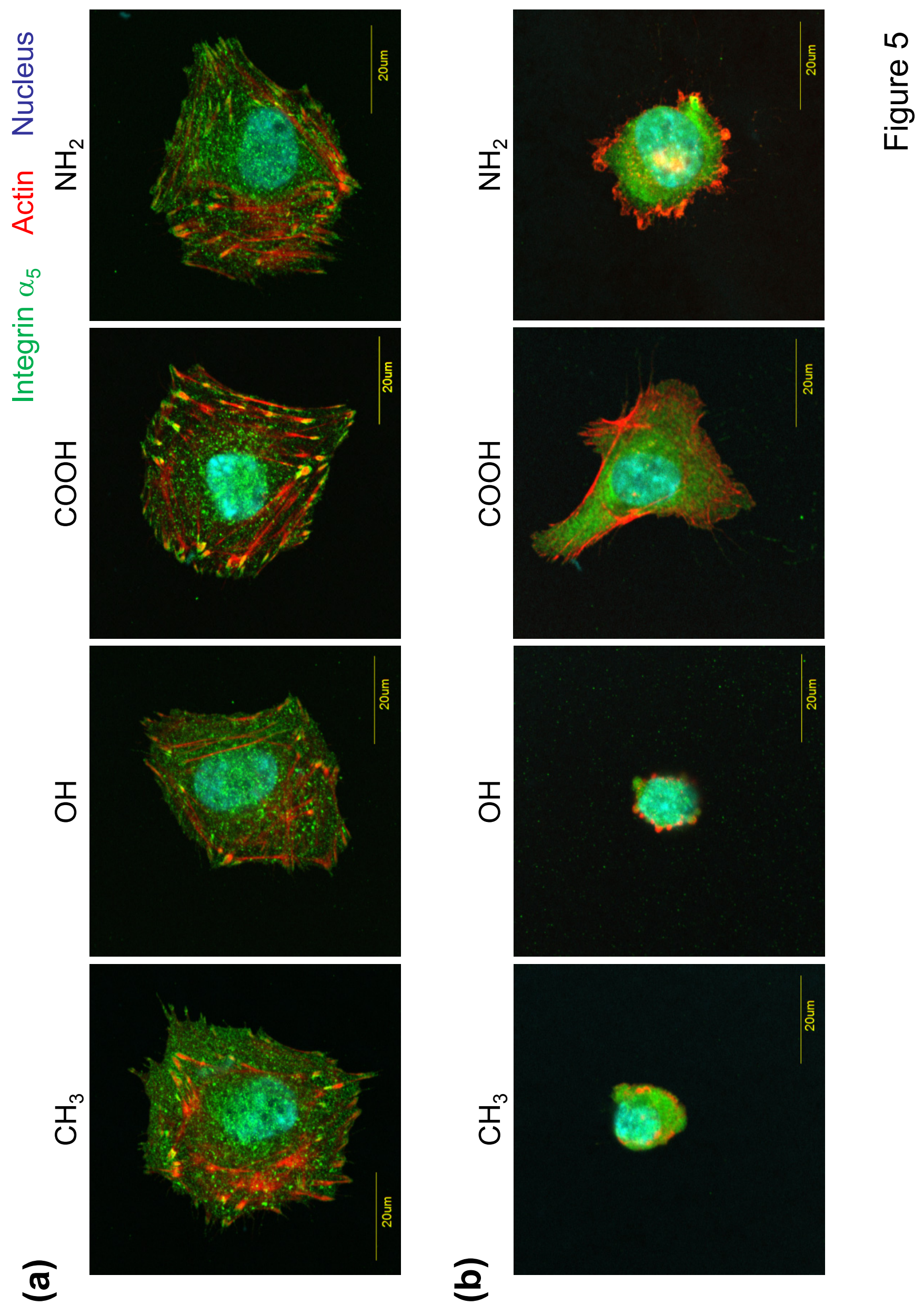

도 

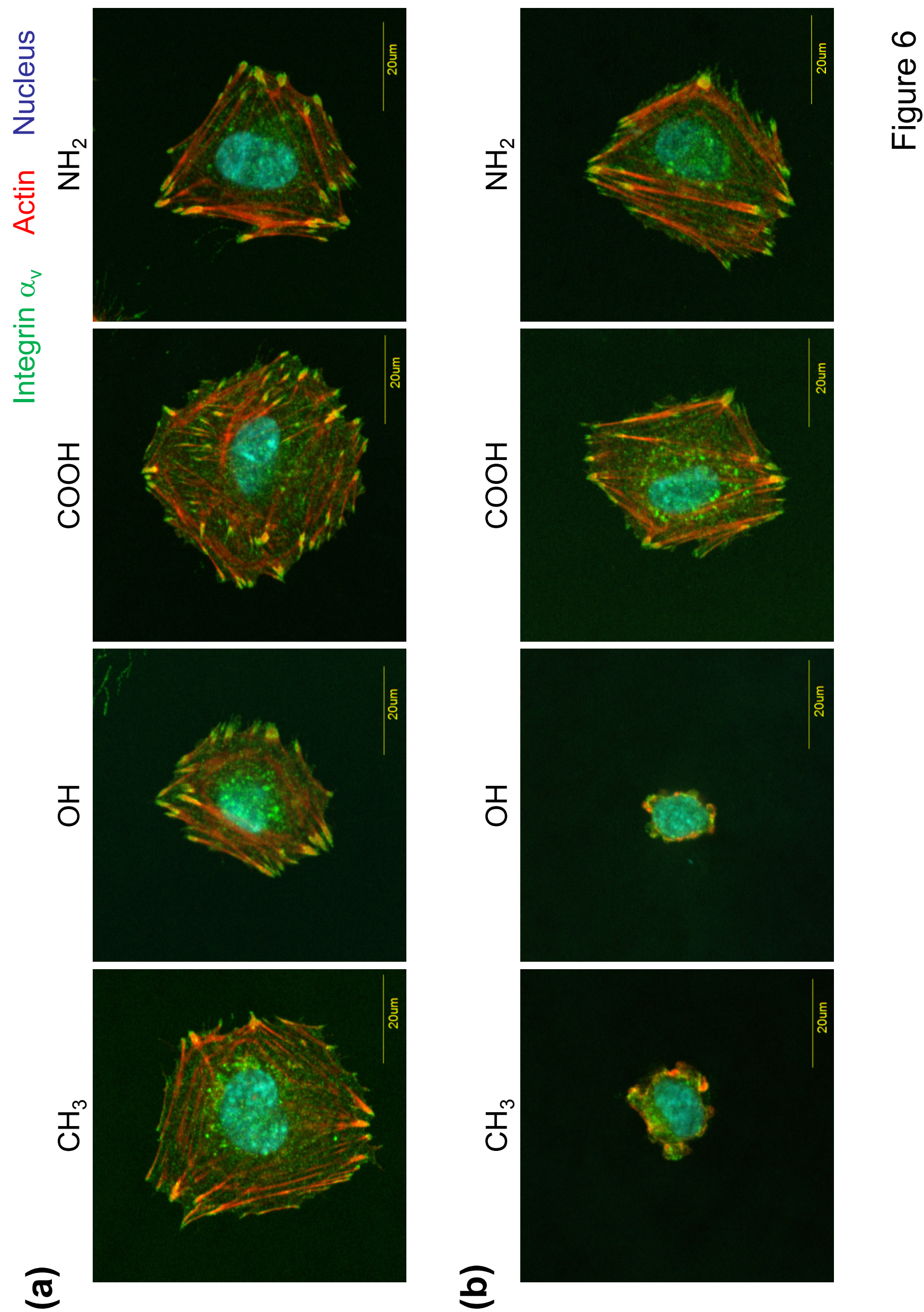


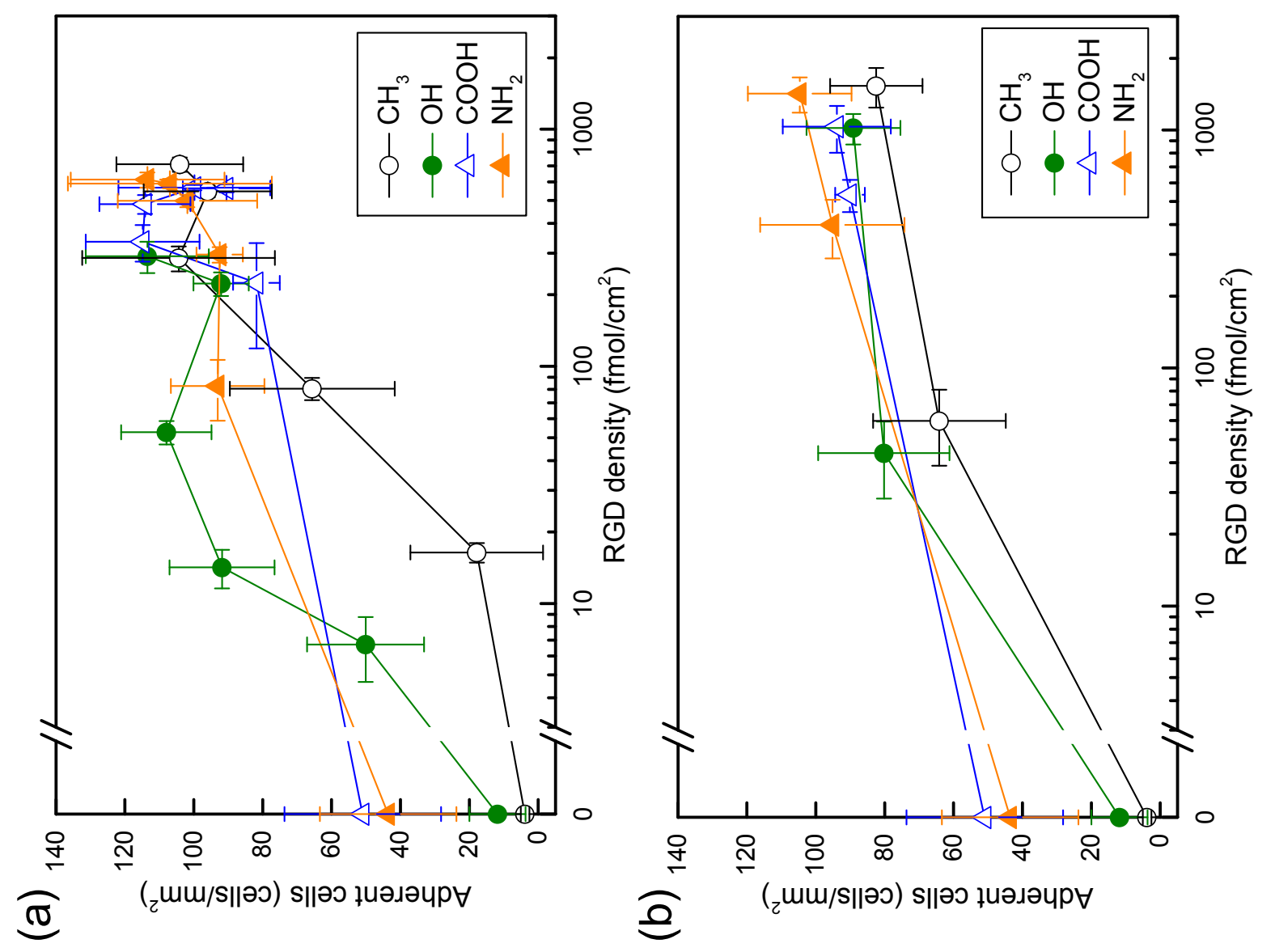




\section{Supplementary Figure}

Preferential adsorption of cell adhesive proteins from complex media on self-assembled monolayers and its effect on subsequent cell adhesion

Yusuke Arima and Hiroo Iwata*

Institute for Frontier Medical Sciences, Kyoto University, 53 Kawahara-cho, Shogoin, Sakyo-ku, Kyoto 606-8507, Japan

\section{Total amount of adsorbed proteins onto SAMs}

\section{$\underline{\text { Experimental }}$}

BK-7 glasses ( 10 x $25 \mathrm{~mm}$, thickness: $1 \mathrm{~mm})$ were cleaned by oxygen plasma treatment using a plasma cleaner (FEMTO; Diener Electronic GmbH + Co., Germany) for $1 \mathrm{~min}$, and rinsed with highly purified water (18.2 M $\Omega$ ) and with 2-propanol three times. The cleaned glasses were coated with a chromium underlayer of $1 \mathrm{~nm}$ and then a gold layer of $49 \mathrm{~nm}$ in thickness by a thermal evaporation apparatus (V-KS200, Osaka Vacuum Instruments, Osaka, Japan). The gold-coated glasses were immediately immersed in 1 $\mathrm{mM}$ alkanethiol solutions overnight at room temperature to form mixed SAMs. The glasses were then rinsed with ethanol and water twice and finally with ethanol, and then 
dried under a stream of nitrogen gas.

A surface plasmon resonance (SPR) instrument was assembled by utilizing the Kretschmann configuration as previously reported [1]. The SAM-coated glass plate was coupled to a hemicylindrical prism with an immersion oil $(n=1.515$, Cargille Laboratories, Ceder Grove, NJ) and the SPR flow cell was attached on the plate. A peristaltic pump (Tokyo Rikakikai Co., Ltd., Tokyo, Japan) delivered the liquid sample to the flow cell at $1 \mathrm{~mL} / \mathrm{min}$. For background correction, a blank buffer solution of DPBS was allowed to flow across the SAM surface. All of experiments were performed at $37^{\circ} \mathrm{C}$.

The SAM surface was first exposed to DPBS, and a protein solution (mixture of Fn/BSA or Vn/BSA) was injected in the flow cell, and then left for $30 \mathrm{~min}$. DPBS was then circulated for $5 \mathrm{~min}$ to wash out the protein solution and weakly adsorbed proteins. The total amount of adsorbed proteins was determined by SPR angle shifts, using the following relationship [1], supposing refractive indices and densities of proteins to be 1.45 and $1 \mathrm{~g} / \mathrm{cm}^{3}$

The amount of adsorbed protein $\left(\mathrm{ng} / \mathrm{cm}^{2}\right)$

$$
=500 \times \text { increase of the resonance angle }(\text { degree })
$$


$\underline{\text { Result }}$

(a)

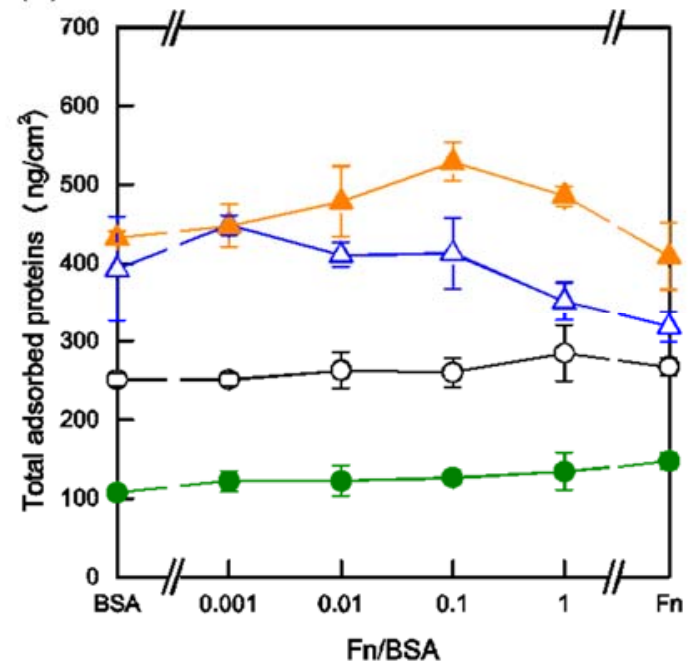

(b)

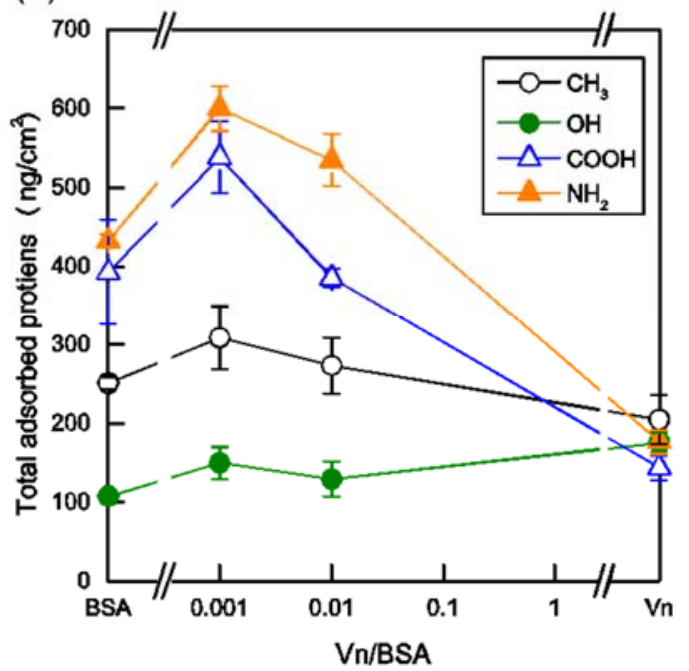

Supplementary Figure. Total amount of adsorbed proteins onto SAMs carrying different functionalities as a function of the weight ratio of Fn to BSA (a) and Vn to BSA. Concentrations of Fn and Vn were kept constant $(10 \mu \mathrm{g} / \mathrm{mL})$ for a series of experiments. Fn, $\mathrm{Vn}$, and BSA in $\mathrm{X}$-axes indicate single solution used for protein adsorption experiments (Fn, Vn: $10 \mu \mathrm{g} / \mathrm{mL}, \mathrm{BSA}: 10 \mathrm{mg} / \mathrm{mL})$. Data shown are means $\pm \mathrm{SD}(n=3)$.

\section{$\underline{\text { References }}$}

Hirata I, Morimoto Y, Murakami Y, Iwata H, Kitano E, Kitamura H, Ikada Y. Study of complement activation on well-defined surfaces using surface plasmon resonance. Colloids Surf B 2000;18:285-292. 